Check for updates

Cite this: RSC Adv., 2017, 7, 34287

Received 17th April 2017

Accepted 28th June 2017

DOI: $10.1039 / c 7 r a 04317 a$

rsc.li/rsc-advances

\section{A 1,8-naphthalimide-based fluorescent probe for selective and sensitive detection of peroxynitrite and its applications in living cell imaging $\dagger$}

\begin{abstract}
Xiulan Li,ł Jingli Hou,ł Chao Peng, Li Chen, Wenbo Liu and Yangping Liu (D)*
Peroxynitrite $\left(\mathrm{ONOO}^{-}\right)$is an extremely reactive oxygen species which can damage a wide array of biomolecules in cells and eventually result in mitochondrial dysfunction and cell death. Detection and imaging of this species is of significant importance to understand its role in biological processes. However, current methods are mostly limited by low sensitivity and/or specificity. In this work, we designed and synthesized a new 1,8-naphthalimide-based turn-on fluorescent probe NP for $\mathrm{ONOO}^{-}$in which the 1,8-naphthalimide fluorophore was directly conjugated with a methyl(4-hydroxyphenyl)amino group. The reaction of NP with $\mathrm{ONOO}^{-}$led to the oxidative $\mathrm{N}$-dearylation of the methyl(4hydroxyphenyl)amino group and produced a highly fluorescent product NP-P. The probe NP exhibited high sensitivity for $\mathrm{ONOO}^{-}$with a detection limit of $11 \mathrm{nM}$ and high specificity over other reactive species in phosphate buffer. Moreover, NP was used to specifically detect $\mathrm{ONOO}^{-}$generated in RAW264.7 murine macrophages upon stimulation by LPS and IFN- $\gamma$. Our present study sheds light on the design of new probes for $\mathrm{ONOO}^{-}$and the resulting probe NP has great potential in enabling selective and specific detection and imaging of $\mathrm{ONOO}^{-}$in different biological and chemical systems.
\end{abstract}

\section{Introduction}

Peroxynitrite $\left(\mathrm{ONOO}^{-}\right)$, a highly reactive oxidant and efficient nitrating agent in living systems, is endogenously generated through the diffusion-controlled reaction of nitric oxide (NO) and superoxide $\left(\mathrm{O}_{2}{ }^{-}\right) .{ }^{\mathbf{1 , 2}}$ This species can react with a wide array of biomolecules such as proteins, lipids, and nucleic acids, resulting in cell death. As a result, $\mathrm{ONOO}^{-}$is closely related to a variety of diseases, including Alzheimer's disease, arthritis, cancer, autoimmune and inflammatory diseases, and other disorders. $^{3-6}$ On the other hand, accumulating evidence has demonstrated that $\mathrm{ONOO}^{-}$plays positive roles in either signal transduction via nitrating tyrosine residues ${ }^{7}$ or immunogenic response against invading pathogens. ${ }^{8-10}$ Therefore, development of specific methods for detection of cellular $\mathrm{ONOO}^{-}$is of considerable significance for both diagnosis of pertinent diseases and exploration of its diverse pathophysiology.

Fluorescent probes have been recognized as the most efficient molecular tools for detection and imaging of trace amounts of biomolecules in biological systems due to their simplicity, sensitivity, visualization, real-time analysis and

Tianjin Key Laboratory on Technologies Enabling Development of Clinical Therapeutics and Diagnostics, School of Pharmacy, Tianjin Medical University, Tianjin 300070, P. R. China. E-mail: liuyangping@tmu.edu.cn

$\dagger$ Electronic supplementary information (ESI) available: Experimental procedures, characterization data and additional spectra. See DOI: $10.1039 / \mathrm{c} 7 \mathrm{ra04317a}$

\$ These authors contribute equally to this work. noninvasiveness. ${ }^{11-14}$ The early-stage fluorescent $\mathrm{ONOO}^{-}$probes were based on the reduced non-fluorescent rhodamine or fluorescein dyes, which could be converted into fluorescent products upon oxidization by $\mathrm{ONOO}^{-} .^{15-19}$ However, the interference from other reactive oxygen species (ROS) such as ${ }^{\circ} \mathrm{OH}$ and $\mathrm{ClO}^{-}$was not negligible when using these probes. To overcome this issue, small-molecule fluorescent probes with the improved selectivity were developed on the base of the $\mathrm{ONOO}^{-}$triggered specific reactions, including aromatic nitration, ${ }^{20}$ formation of dioxirane with activated ketones, ${ }^{21-23}$ oxidation of organoselenium/organotellurium, ${ }^{24-26}$ phenol $^{27}$ or 4-hydroxyaniline groups, ${ }^{28,29}$ chemical transformation of boronic acid ${ }^{30,31}$ or boronate ${ }^{32-34}$ to phenol, and so on. ${ }^{35,36}$ Recently, fluorescent probes displaying the reversible reactions with ROS have accepted much attention. ${ }^{37,38}$

1,8-Naphthalimide has served as an attractive fluorophore owing to its intense fluorescence, high sensitivity, good photostability and insensitivity to $\mathrm{pH}$ in the physiological range. ${ }^{39-41}$ Herein, we present design and synthesis of a new 1,8naphthalimide-based fluorescent probe by direct conjugation of the 1,8-naphthalimide fluorophore with a methyl(4hydroxyphenyl)amino reaction group, which has high selectivity to $\mathrm{ONOO}^{-} .{ }^{29}$ It can be expected that the probe NP is nonfluorescent due to the PET process from the methyl(4hydroxyphenyl) amino group with high electron density to the excited fluorophore. However, robust fluorescence can be observed due to the production of the green-emission product NP-P upon from oxidative $N$-dearylation of the methyl(4- 


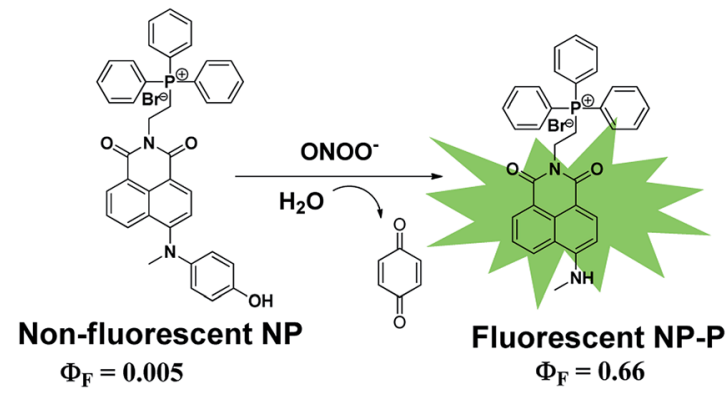

Scheme 1 Proposed sensing mechanism of the probe NP for $\mathrm{ONOO}^{-}$

hydroxyphenyl)amino group in $\mathrm{NP}$ by $\mathrm{ONOO}^{-}$(Scheme 1). We hypothesized that NP could be an ideal probe for detecting intracellular $\mathrm{ONOO}^{-}$due to the following virtues: high sensitivity and selectivity to $\mathrm{ONOO}^{-}$, insensitivity to $\mathrm{pH}$ and high photostability. Incorporation of the lipophilic triphenylphosphonium (TPP) cation group into 1,8-naphthalimide core is very helpful to facilitate its accumulation within cells since such lipophilic cations are shown to easily permeate lipid bilayers, driven by the membrane potential. ${ }^{42}$

\section{Material and methods}

\subsection{Synthesis of NP}

The probe NP was synthesized using the route as shown in Scheme 2. In brief, 4-bromo-1,8-naphthalic anhydride 1 reacted with 4 -(methylamino)phenol 2 in NMP at $140{ }^{\circ} \mathrm{C}$ to afford the intermediate 3 , which was further conjugated with (2-aminoethyl)triphenylphosphonium bromide $\mathbf{4}$ in the presence of DMAP at reflux in ethanol to give the desirable compound NP as a reddish-brown solid. The resulting fluorescent probe NP was well characterized by ${ }^{1} \mathrm{H}-\mathrm{NMR},{ }^{13} \mathrm{C}-\mathrm{NMR}$ and HRMS (Fig. S1-S4†).

\subsection{Preparation of the test solution}

Deionized water and spectroscopic grade ethanol were used for spectroscopic studies. Peroxynitrite $\left(\mathrm{ONOO}^{-}\right)$solution was prepared as reported ${ }^{42}$ and its concentration was estimated by using an extinction coefficient of $1670 \mathrm{M}^{-1} \mathrm{~cm}^{-1}$ at $302 \mathrm{~nm}$ $\left[C_{\mathrm{ONOO}^{-}}=\mathrm{Abs}_{302} \mathrm{~nm} / 1.67(\mathrm{mM})\right]$. Superoxide solution $\left(\mathrm{O}_{2}{ }^{--}\right)$was

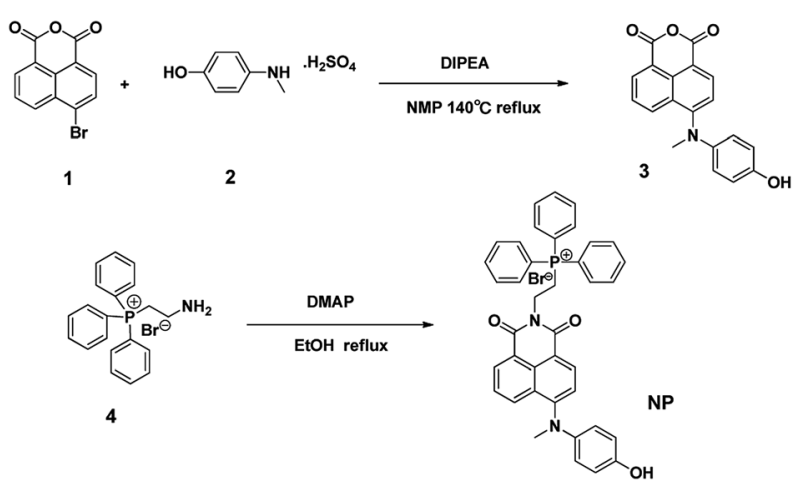

Scheme 2 Synthetic route of NP. prepared by adding $\mathrm{KO}_{2}(1 \mathrm{mg})$ to dry dimethyl sulfoxide $(1 \mathrm{~mL})$ and the solution was stirred vigorously for $10 \mathrm{~min} . \mathrm{H}_{2} \mathrm{O}_{2}$ solution was prepared by dilution of commercial $\mathrm{H}_{2} \mathrm{O}_{2}$ solution (30\%) in deionized water. Hydroxyl radical $\left(\mathrm{OH}^{*}\right)$ was generated in situ by adding $\mathrm{FeCl}_{2}$ into 10 equiv. of $\mathrm{H}_{2} \mathrm{O}_{2}$ solution. ROO' was generated from 2,2'-azobis(2-amidinopropane)dihydrochloride, which was firstly dissolved in deionized water and then added into the probe testing solutions at $37^{\circ} \mathrm{C}$ for $1 \mathrm{~h}$. Nitric oxide (NO) was generated from NO donor of $\beta$-Gal-NONoate $(10 \mu \mathrm{M})$ with $\beta$ galactosidase (2 unit) at $37^{\circ} \mathrm{C}$.

\subsection{Cell culture}

RAW264.7 macrophage cells were kindly provided by Laboratory of Epigenetics in Development and Tumorigenesis Department of Cell Biology of Tianjin Medical University. Cells were grown in RPMI 1640 medium supplemented with $10 \%$ Fetal Bovine Serum (FBS) and $1 \%$ antibiotics at $37{ }^{\circ} \mathrm{C}$ in a $5 \% \mathrm{CO}_{2} / 95 \%$ air incubator in a humidified atmosphere.

\subsection{Imaging the stimulation induced by $\mathrm{ONOO}^{-}$in RAW264.7 murine macrophages}

For imaging exogenously added $\mathrm{ONOO}^{-}$, the cells were pretreated with NP $(5 \mu \mathrm{M})$ for $30 \mathrm{~min}$, and then incubated with $\mathrm{ONOO}^{-}(50 \mu \mathrm{M})$ donor SIN-1 for $30 \mathrm{~min}$ at $37^{\circ} \mathrm{C}$ in DMEM medium. For imaging the endogenous $\mathrm{ONOO}^{-}$, the cells were pretreated with $1 \mu \mathrm{g} \mathrm{mL} \mathrm{m}^{-1}$ LPS and $50 \mathrm{ng} \mathrm{mL}{ }^{-1} \mathrm{INF}-\gamma$ for $4 \mathrm{~h}$ in DMEM medium at $37^{\circ} \mathrm{C}$, and then incubated with probe NP $(5$ $\mu \mathrm{M})$ for $30 \mathrm{~min}$ at $37^{\circ} \mathrm{C}$ in the same medium. For inhibition assays, the cells were activated with LPS $\left(1 \mu \mathrm{g} \mathrm{mL}{ }^{-1}\right)$ and INF- $\gamma$ (50 $\mathrm{ng} \mathrm{mL} \mathrm{mL}^{-1}$ ) in the presence of LAME (5 mM) or TEMPO (300 $\mu \mathrm{M})$ for $4 \mathrm{~h}$, and then loaded with probe NP $(5 \mu \mathrm{M})$ for $30 \mathrm{~min}$. After each treatment, the cells were washed with PBS for 3 times. Images were acquired through Olympus Fluo View ${ }^{\mathrm{TM}}$ FV1200 confocal microscope with band path of 500-600 nm upon excitation of NP at $488 \mathrm{~nm}$.

\section{Results and discussion}

\subsection{Reactivity and selectivity of NP toward $\mathrm{ONOO}^{-}$}

The reaction of NP with $\mathrm{ONOO}^{-}$was tested using HPLC and LCMS analysis. NP $(4 \mu \mathrm{M})$ was stable in phosphate buffer solution $(100 \mathrm{mM}, \mathrm{pH}$ 7.4), and its retention time on the reversed $\mathrm{C} 18$ column was 18.5 min with the parent ion $\mathrm{M}^{+}$at $\mathrm{m} / z 607.2$ as a phosphonium cation (see details in ESI $\dagger$ ). After addition of $\mathrm{ONOO}^{-}$(10 equiv.), a new peak with a retention time of $15.6 \mathrm{~min}$ appeared with the parent ion $\mathrm{M}^{+}$at $m / z 515.2$ (Fig. 1), consistent with the expected product (NP-P) of the $N$-dearylation reaction. These results demonstrated that NP could be dearylated upon treatment with $\mathrm{ONOO}^{-}$to generate NP-P as showed in Fig. 1 .

To verify whether the $\mathrm{N}$-dearylation of NP induced by $\mathrm{ONOO}^{-}$ is concentration-dependent, we examined the fluorescent response of NP towards $\mathrm{ONOO}^{-}$. As shown in Fig. 2A, NP $(1 \mu \mathrm{M})$ in PBS (100 mM, pH 7.4) only showed weak fluorescence with an emission maximum at $545 \mathrm{~nm}(\Phi=0.005)$, indicative of highly efficient fluorescence quenching by the phenol group. Upon addition of $\mathrm{ONOO}^{-}$, the fluorescence intensity at $545 \mathrm{~nm}$ 


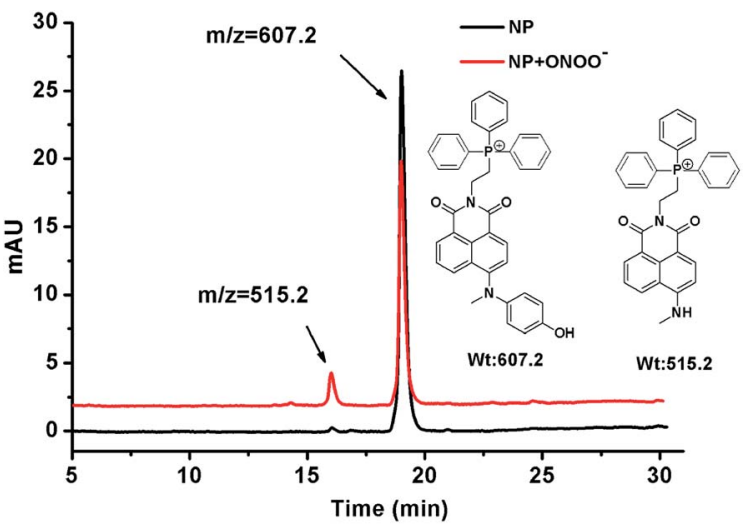

Fig. 1 LC-MS analysis for the reaction of NP with $\mathrm{ONOO}^{-}$. See details in ESI. $\dagger$

gradually increased due to the production of the highly fluorescent NP-P ( $\Phi=0.66$, Fig. $2 \mathrm{~A})$. The fluorescent intensity reaches the maximum value when 15 equiv. of $\mathrm{ONOO}^{-}$was added, and a $>12$-fold enhancement in the fluorescence intensity was observed. Further addition of $\mathrm{ONOO}^{-}$resulted in a slight decrease of the fluorescent intensity (Fig. 2A). The fluorescence intensity at $545 \mathrm{~nm}$ was linearly related to the concentrations of
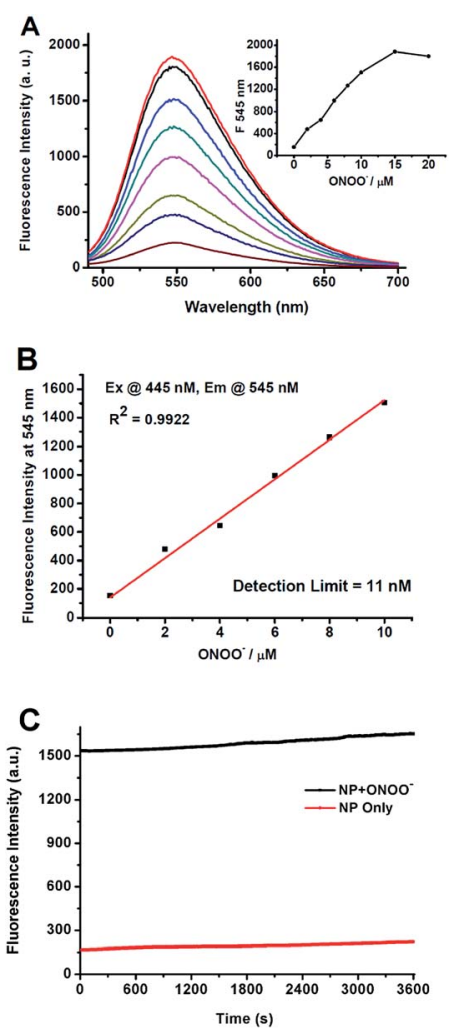

Fig. 2 (A) Fluorescence response of NP $(1 \mu \mathrm{M})$ towards the concentrations of $\mathrm{ONOO}^{-}$(from bottom line to top line: $0-20 \mu \mathrm{M}$ ) in PBS; (B) the corresponding linear relationship between the fluorescent intensity and the concentrations of $\mathrm{ONOO}^{-} ;$(C) the fluorescent changes of $\mathrm{NP}(1 \mu \mathrm{M})$ and its reaction mixture with $\mathrm{ONOO}^{-}(10 \mu \mathrm{M})$ against light (445 nm).
$\mathrm{ONOO}^{-}$in the range of 0 to $10 \mu \mathrm{M}\left(R^{2}=0.99\right)$ (Fig. 2B). And the detection limit of $11 \mathrm{nM}$ was calculated based on $3 \sigma / \kappa$. This value was comparable to those of other peroxynitrite probes such as HKGreen-4 $(10 \mathrm{nM})^{43}$ and MITO-CC $(11.3 \mathrm{nM}) \cdot{ }^{44}$ The low detection limit indicated that NP was highly sensitive to $\mathrm{ONOO}^{-}$.

While the sensitivity depends strongly on the fluorescence brightness of a probe before and after its reactivity with $\mathrm{ONOO}^{-}$, photo bleaching by a strong laser excitation may also lead to less sensitivity. Therefore, the stability of the product NP-P against light was investigated. The reaction mixture containing $\mathrm{ONOO}^{-}$ $(10 \mu \mathrm{M})$ and NP $(1 \mu \mathrm{M})$ in PBS was exposed to a long-term irradiation with light $(445 \mathrm{~nm})(1 \mathrm{~h})$. As shown in Fig. 2C, no significant decrease of its fluorescence was observed, indicating that NP-P was highly photostable. Similar photostability was also observed for NP except for the weaker fluorescence for NP. Therefore, NP can be applied for long-term measurement or imaging of $\mathrm{ONOO}^{-}$.

In addition to high reactivity, high selectivity is also required for NP as a good probe to detect $\mathrm{ONOO}^{-}$in biological systems. For this purpose, the reactivity of NP towards various biologically relevant ROS, such as $\mathrm{H}_{2} \mathrm{O}_{2},{ }^{\circ} \mathrm{OH}, \mathrm{O}_{2}{ }^{--}$, $\mathrm{HOCl}$, ROO ${ }^{\circ}$ and NO was also examined. Fig. 3 showed that almost no fluorescence enhancement was observed when excess (10 equiv.) of each species including $\mathrm{NO},{ }^{\circ} \mathrm{OH}, \mathrm{HOCl}$ and $\mathrm{ROO}^{\circ}$ was added into the NP solution $(1 \mu \mathrm{M})$ in PBS. And only a 2 -fold enhancement of fluorescence was observed after addition of $\mathrm{O}_{2}{ }^{\cdot-}$ or $\mathrm{H}_{2} \mathrm{O}_{2}$ as compared to a 12 -fold enhancement of fluorescence in the case of $\mathrm{ONOO}^{-}$. Meanwhile, the fluorescence response of NP towards reducing agents, amino acids and metal ions was also investigated (Fig. S6†). No significant fluorescence enhancements were observed upon treatment of NP with these agents. Collectively, NP has high selectivity and sensitivity toward $\mathrm{ONOO}^{-}$over other ROS, biologically related agents and metal ions, thus allowing for further investigation on imaging $\mathrm{ONOO}^{-}$in cells.

\subsection{Effect of $\mathrm{pH}$ on the fluorescence response of NP toward ONOO $^{-}$}

We also evaluated the reactivity of $\mathrm{NP}$ with $\mathrm{ONOO}^{-}$at different pHs. As shown in Fig. 4A, NP displayed pH-dependent reactivity to $\mathrm{ONOO}^{-}$with the significant fluorescence response in the $\mathrm{pH}$

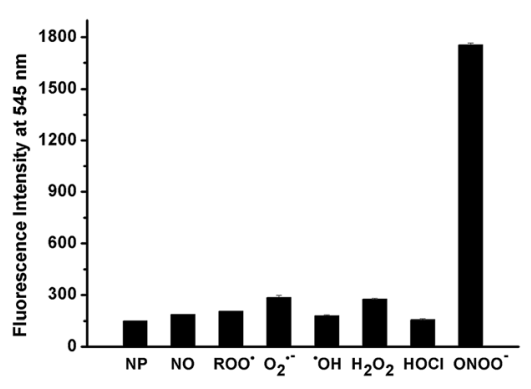

Fig. 3 Comparison of the fluorescence responses of NP $(1 \mu \mathrm{M})$ toward $\mathrm{ONOO}^{-}$and other ROS (10 $\mu \mathrm{M}$ for all ROS) in PBS (100 mM, pH 7.4) at $25^{\circ} \mathrm{C}$. 
A
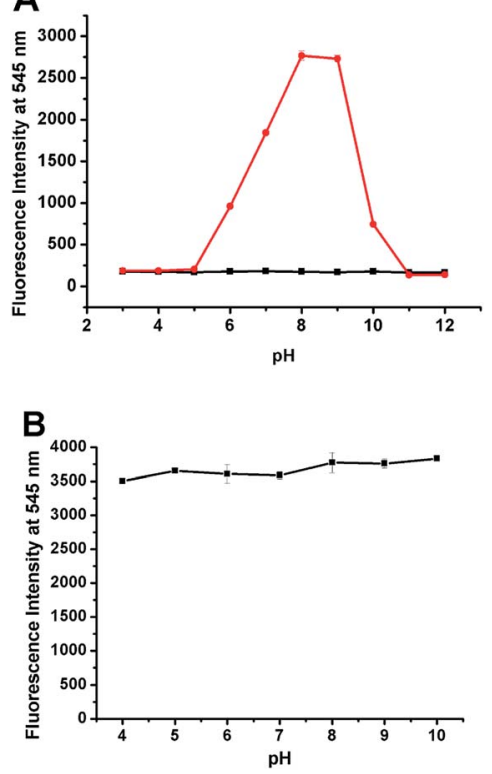

Fig. 4 (A) The fluorescence response of NP $(1 \mu \mathrm{M})$ towards $\mathrm{ONOO}^{-}$ $(10 \mu \mathrm{M})$ in PBS $(100 \mathrm{mM})$ with different $\mathrm{pHs}$ from 4 to 10 . The solution of $\mathrm{ONOO}^{-}$was added to the solution of NP in PBS with the designated $\mathrm{pH}$. Then, the fluorescent intensity of the reaction mixture was measured. (B) The $\mathrm{pH}$ effect on the fluorescence intensity of the product from the reaction of NP with $\mathrm{ONOO}^{-}$. The solution of NP in DMSO was initially mixed with the aqueous solution of $\mathrm{ONOO}^{-}$and the resulting solution was further diluted with PBS $(100 \mathrm{mM})$ to afford the final concentrations of NP $(1 \mu \mathrm{M})$ and $\mathrm{ONOO}^{-}(10 \mu \mathrm{M})$. Then, the fluorescent spectra were recorded and the fluorescent intensities were measured. $\lambda_{\mathrm{ex}}=445 \mathrm{~nm}$ and $\lambda_{\mathrm{em}}=545 \mathrm{~nm}$. Slits: $10 / 10 \mathrm{~nm}$, voltage: $700 \mathrm{~V}$. range of 6-10 with an emission maximum at $545 \mathrm{~nm}$ after adding specific amount of $\mathrm{ONOO}^{-}$. And the enhancement was strongest in the $\mathrm{pH}$ range of $8-9$, indicating that the probe $\mathrm{NP}$ can be used to detect $\mathrm{ONOO}^{-}$at physiological conditions. Furthermore, considering that $\mathrm{pH}$ within cells varies in a wide range, the effect of $\mathrm{pH}$ on the fluorescence of the product NP-P was also investigated. The $\mathrm{pH}$ values in the system were adjusted by adding high concentrations of PBS (100 mM) with designated pHs to the reaction mixture of $\mathrm{ONOO}^{-}$and NP. As shown in Fig. 4B, the intensity was almost the same across the $\mathrm{pH}$ values from 4 to 10 indicating that the fluorescence of NP-P was insensitive to $\mathrm{pH}$. The above results indicated that the probe $\mathrm{NP}$ is well suitable to detect $\mathrm{ONOO}^{-}$in the wide range of pHs.

\subsection{Bioimaging of $\mathrm{ONOO}^{-}$in RAW264.7 cells}

$\mathrm{NP}$ was used to detect $\mathrm{ONOO}^{-}$generated from RAW264.7 murine macrophages which are known to produce $\mathrm{ONOO}^{-}$ upon stimulation with interferon- $\gamma(\mathrm{IFN}-\gamma)$ and lipopolysaccharide (LPS). ${ }^{45}$ As shown in Fig. 5B, when the cells were incubated with NP $(5 \mu \mathrm{M})$, a very weak green fluorescence was observed due to endogenous $\mathrm{ONOO}^{-}$from macrophages on rest. Pretreatment of the cells with the $\mathrm{ONOO}^{-}$donor SIN-1 (3morpholinosydnonimine $)^{46}$ induced the marked fluorescence enhancement (Fig. 5C). Similarly, a strong fluorescence was observed when the cells were stimulated with IFN- $\gamma /$ LPS (Fig. 5D). In order to confirm that the fluorescence originates from $\mathrm{ONOO}^{-}$, the cells were pretreated with either 2,2,6,6-tetramethylpiperidine- $N$-oxyl (TEMPO, the $\mathrm{O}_{2}{ }^{-{ }^{-}}$scavenger) ${ }^{47}$ or labdanolic acid methyl ester (LAME, nitric oxide synthase inhibitor) before stimulation with IFN- $\gamma /$ LPS. The almost
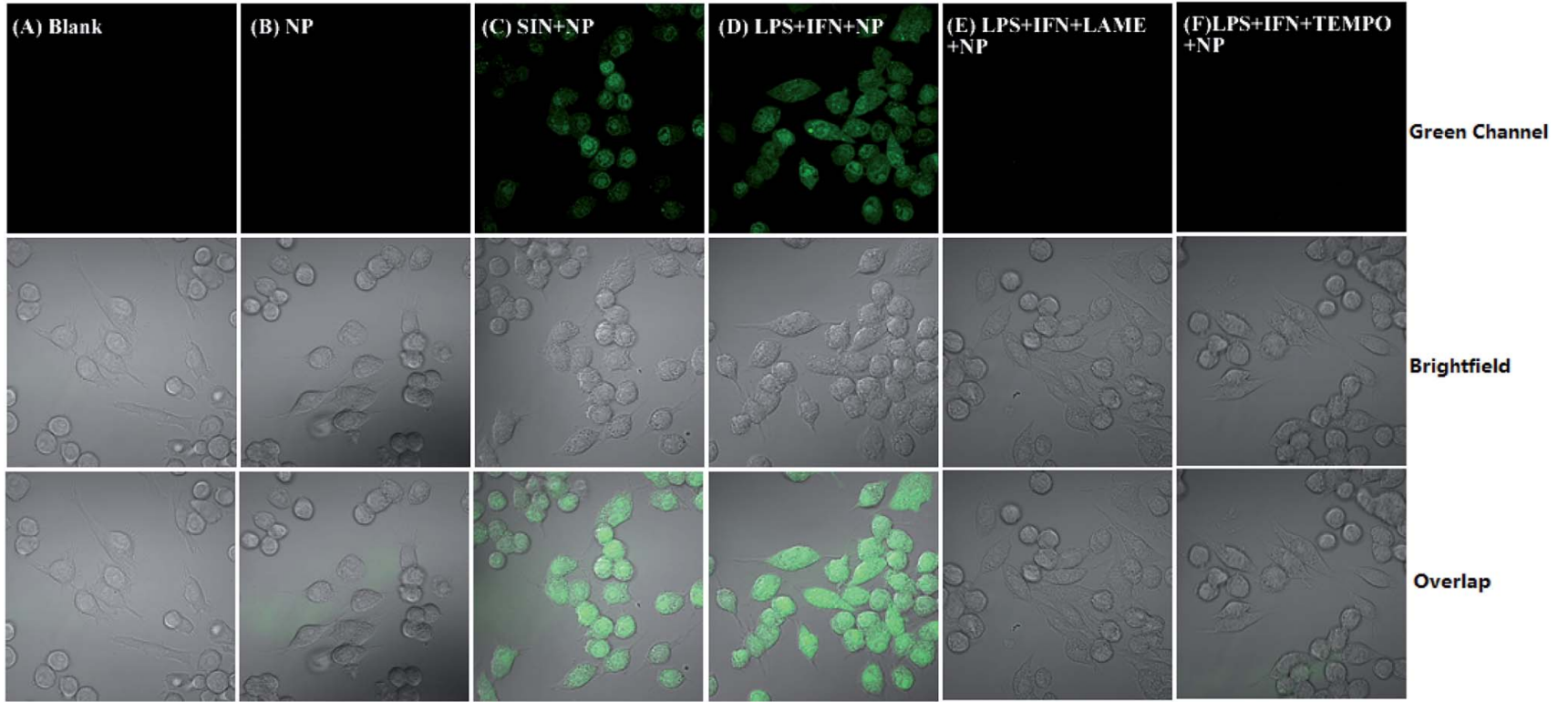

Fig. 5 Fluorescence images of $\mathrm{ONOO}^{-}$by NP in RAW264.7 murine macrophages under different conditions; (A) blank; (B) cells were treated with NP $(5 \mu \mathrm{M}$,$) for 30$ min and then imaged; (C) NP-loaded cells were treated with SIN-1 (50 $\mu \mathrm{M}, 30$ min) and then imaged; (D) cells were stimulated with both LPS $\left(1 \mu \mathrm{g} \mathrm{mL}^{-1}\right)$ and IFN- $\gamma\left(50 \mathrm{ng} \mathrm{mL}^{-1}\right)$ for $4 \mathrm{~h}$ and then treated with NP $(5 \mu \mathrm{M}, 30 \mathrm{~min})$; (E) NOS inhibitor LAME (5 mM) was co-incubated with LPS $\left(1 \mu \mathrm{g} \mathrm{mL}^{-1}\right) / \mathrm{IFN}-\gamma\left(50 \mathrm{ng} \mathrm{mL}^{-1}\right)$ and then with NP (5 $\left.\mu \mathrm{M}, 30 \mathrm{~min}\right)$; (F) superoxide inhibitor TEMPO (300 $\left.\mu \mathrm{M}\right)$ was coincubated with LPS/IFN- $\gamma$ stimulation and then with NP (5 $\mu \mathrm{M}, 30 \mathrm{~min})$; excitation wavelength $=445 \mathrm{~nm}$; emission wavelength $=500-600 \mathrm{~nm}$. 
complete inhibition of the fluorescence enhancements by TEMPO or LAME indicates that NP is specifically sensitive to $\mathrm{ONOO}^{-}$in RAW264.7 cells. To verify if NP could be accumulated in mitochondria due to the TPP cation group, the macrophages were pretreated with NP and MitoTracker Red. After extensive washing with PBS, the cells were incubated with SIN-1 $(50 \mu \mathrm{M})$ for $30 \mathrm{~min}$. The overlaid images (Fig. S7†) clearly showed that the NP probe was not site-specifically localized into the mitochondria but with additional distribution in the nuclear. The nonspecific distribution property of NP may be due to its lower hydrophobicity which has a significant role in controlling the targeting property of the TPP group. ${ }^{\mathbf{4 8 , 4 9}}$ No significant cytotoxicity of NP below $5 \mu \mathrm{M}$ (Fig. S8 $\dagger$ ) further ensures the use of NP in biological systems. These results consistently confirm that the probe NP with good biocompatibility can be used for bioimaging of $\mathrm{ONOO}^{-}$in cells.

\section{Conclusions}

In the present study, we synthesized a novel fluorescent probe $\mathrm{NP}$ for $\mathrm{ONOO}^{-}$by the direct conjugation of a 1,8-naphthalimide dye with a sensitive methyl(4-hydroxyphenyl)amino reaction group. The reaction of the probe NP with $\mathrm{ONOO}^{-}$resulted in the oxidative $\mathrm{N}$-dearylation to release the fluorescent product NP-P, as verified by LC-MS. NP exhibits high sensitivity to $\mathrm{ONOO}^{-}$ with a detection limit of $11 \mathrm{nM}$. Moreover, this probe also shows high selectivity to $\mathrm{ONOO}^{-}$over various reactive species and strong fluorescent response to $\mathrm{ONOO}^{-}$at $\mathrm{pHs}$ from 7 to 9. High biocompatibility and photostability guarantee the wide use of $\mathrm{NP}$ in biological systems. Using a laser scanning confocal microscope, the specific imaging of the exogenous and stimulation-induced $\mathrm{ONOO}^{-}$in RAW264.7 murine macrophages was successfully achieved. Taken together, our new probe is well suitable for detection and imaging of $\mathrm{ONOO}^{-}$in biological systems which would deepen our understanding of various pathophysiological roles of $\mathrm{ONOO}^{-}$in cellular processes.

\section{Acknowledgements}

This work was financially supported by the National Natural Science Foundation of China (No. 81603064, 21572161 and 31500684), Science \& Technology Projects of Tianjin (15JCZDJC32300 and 15JCYBJC23700) and Foundation of Tianjin Medical University (2110/2YY033).

\section{Notes and references}

1 R. Radi, J. Biol. Chem., 2013, 288, 26464-26472.

2 G. Ferrersueta and R. Radi, ACS Chem. Biol., 2009, 4, 161177.

3 C. Szabo, H. Ischiropoulos and R. Radi, Nat. Rev. Drug Discovery, 2007, 6, 662-680.

4 P. Pacher, J. S. Beckman and L. Liaudet, Physiol. Rev., 2007, 87, 315-424.

5 T. Nagano, J. Clin. Biochem. Nutr., 2009, 45, 111-124.
6 G. Ferrer-Sueta and R. Radi, ACS Chem. Biol., 2009, 4, 161177.

7 L. Liaudet, G. Vassalli and P. Pacher, Front. Biosci., Elite Ed., 2009, 14, 4809-4814.

8 R. G. Allen, W. P. Lafuse, N. D. Powell, J. I. Webster Marketon, L. M. Stiner-Jones, J. F. Sheridan and M. T. Bailey, Infect. Immun., 2012, 80, 3429-3437.

9 P. A. Darrah, M. K. Hondalus, Q. Chen, H. Ischiropoulos and D. M. Mosser, Infect. Immun., 2000, 68, 3587-3593.

10 M. N. Alvarez, G. Peluffo, L. Piacenza and R. Radi, J. Biol. Chem., 2011, 286, 6627-6640.

11 J. Du, M. Hu, J. Fan and X. Peng, Chem. Soc. Rev., 2012, 41, 4511-4535.

12 Y. Yang, Q. Zhao, W. Feng and F. Li, Chem. Rev., 2013, 113, 192-270.

13 F. Yu, X. Han and L. Chen, Chem. Commun., 2014, 50, 1223412249.

14 X. Jing, F. Yu and L. Chen, Chem. Commun., 2014, 50, 1425314256.

15 H. Possel, H. Noack, W. Augustin, G. Keilhoff and G. Wolf, FEBS Lett., 1997, 416, 175-178.

16 S. L. Hempel, G. R. Buettner, Y. Q. O'Malley, D. A. Wessels and D. M. Flaherty, Free Radical Biol. Med., 1999, 27, 146159.

17 N. W. Kooy, J. A. Royall, H. Ischiropoulos and J. S. Beckman, Free Radical Biol. Med., 1994, 16, 149-156.

18 N. W. Kooy, J. A. Royall and H. Ischiropoulos, Free Radical Res., 1997, 27, 245-254.

19 G. Y. Wiederschain, Biochemistry, 2011, 76, 1276.

20 T. Ueno, Y. Urano, H. Kojima and T. Nagano, J. Am. Chem. Soc., 2006, 128, 10640-10641.

21 D. Yang, H. L. Wang, Z. N. Sun, N. W. Chung and J. G. Shen, J. Am. Chem. Soc., 2006, 128, 6004-6005.

22 Z. N. Sun, H. L. Wang, F. Q. Liu, Y. Chen, P. K. H. Tam and D. Yang, Org. Lett., 2009, 11, 1887-1890.

23 T. Peng and D. Yang, Org. Lett., 2010, 12, 4932-4935.

24 F. Yu, P. Li, G. Li, G. Zhao, T. Chu and K. Han, J. Am. Chem. Soc., 2011, 133, 11030-11033.

25 N. Li, H. Wang, M. Xue, C. Chang, Z. Chen, L. Zhuo and B. Tang, Chem. Commun., 2012, 48, 2507-2509.

26 F. Yu, P. Li, B. Wang and K. Han, J. Am. Chem. Soc., 2013, 135, 7674-7680.

27 Q. Zhang, Z. Zhu, Y. Zheng, J. Cheng, N. Zhang, Y. T. Long, J. Zheng, X. Qian and Y. Yang, J. Am. Chem. Soc., 2012, 134, 18479-18482.

28 T. Peng, N. K. Wong, X. Chen, Y. K. Chan, D. H. Ho, Z. Sun, J. J. Hu, J. Shen, H. El-Nezami and D. Yang, J. Am. Chem. Soc., 2014, 136, 11728-11734.

29 H. Zhang, J. Liu, Y. Q. Sun, Y. Huo, Y. Li, W. Liu, X. Wu, N. Zhu, Y. Shi and W. Guo, Chem. Commun., 2015, 51, 2721-2724.

30 Z. J. Chen, W. Ren, Q. E. Wright and H. W. Ai, J. Am. Chem. Soc., 2013, 135, 14940-14943.

31 X. Sun, K. Lacina, E. C. Ramsamy, S. E. Flower, J. S. Fossey, X. Qian, E. V. Anslyn, S. D. Bull and T. D. James, Chem. Sci., 2015, 6, 2963-2967. 
32 F. Yu, P. Song, P. Li, B. Wang and K. Han, Analyst, 2012, 137, 3740-3749.

33 J. Kim, J. Park, H. Lee, Y. Choi and Y. Kim, Chem. Commun., 2014, 50, 9353-9356.

34 L. Chen, Z. Xu, J. Li, B. Zhou, M. Shan, Y. Li, L. Liu, B. Li and J. Niu, RSC Adv., 2014, 4, 1025-1031.

35 K. K. Lin, S. C. Wu, K. M. Hsu, C. H. Hung, W. F. Liaw and Y. M. Wang, Org. Lett., 2013, 15, 4242-4245.

36 J. T. Hou, M. Y. Wu, K. Li, J. Yang, K. K. Yu, Y. M. Xie and X. Q. Yu, Chem. Commun., 2014, 50, 8640-8643.

37 Z. Lou, P. Li and K. Han, Acc. Chem. Res., 2015, 48, 13581368.

38 B. Wang, P. Li, F. Yu, P. Song, X. Sun, Z. Lou and K. Han, Chem. Commun., 2013, 49, 1014-1016.

39 T. S. Reddy and A. R. Reddy, Spectrochim. Acta, Part A, 2014, 128, 880-886.

40 C. Wang, X. Zheng, R. Huang, S. Yan, X. Xie, T. Tian, S. Huang, X. Weng and X. Zhou, Asian J. Org. Chem., 2012, 1, 259-263.

41 Y. Kai, Y. Hu, K. Wang, W. Zhi, M. Liang and W. Yang, Spectrochim. Acta, Part A, 2014, 118, 239-243.
42 G. F. Kelso, C. M. Porteous, C. V. Coulter, G. Hughes, W. K. Porteous, E. C. Ledgerwood, R. A. Smithand and M. P. Murphy, J. Biol. Chem., 2001, 276, 4588-4596.

43 T. Peng, N. K. Wong, X. Chen, Y. K. Chan, D. H. Ho, Z. Sun, J. J. Hu, J. Shen, H. EI-Nezami and D. Yang, J. Am. Chem. Soc., 2014, 136, 11728-11734.

44 D. Cheng, Y. Pan, L. Wang, Z. Zeng, L. Yuan, X. Zhang and Y. T. Chang, J. Am. Chem. Soc., 2017, 139, 285-292.

45 R. B. Lorsbach, W. J. Murphy, C. J. Lowenstein, S. H. Snyder and S. W. Russell, J. Biol. Chem., 1993, 268, 1908-1913.

46 N. Ashki, K. C. Hayes and F. Bao, Neuroscience, 2008, 156, 107-117.

47 R. B. R. Muijsers, E. V. D. Worm, G. Folkerts, C. J. Beukelman, A. S. Koster, D. S. Postma and F. P. Nijkamp, Br. J. Pharmacol., 2000, 130, 932-936.

48 M. F. Ross, T. A. Prime, I. Abakumova, A. M. James, C. M. Porteous, R. A. Smith and M. P. Murphy, Biochem. J., 2008, 411, 633-645.

49 M. F. Ross, G. F. Kelso, F. H. Blaikie, A. M. James, H. M. Cochemé, A. Filipovska, T. Da Ros, R. A. Smith and M. P. Murphy, Biochemistry, 2005, 70, 222-230. 